\title{
Molecular Evidence of Rickettsia felis in Phereoeca sp.
}

\author{
Evidência Molecular de Rickettsia felis em Phereoeca sp. \\ Fernanda Sales de Araújo1; Rafael Mazioli Barcelos; Tiago Antônio de Oliveira Mendes; Cláudio Mafra1* (D) \\ ${ }^{1}$ Departamento de Bioquímica e Biologia Molecular, Universidade de Viçosa - UFV, Viçosa. MG, Brasil
}

How to cite: Araújo FS, Barcelos RM, Mendes TAO, Mafra C. Molecular Evidence of Rickettsia felis in Phereoeca sp. Braz J Vet Parasito/ 2021; 30(1): e015620. https://doi.org/10.1590/S1984-29612021017

\begin{abstract}
Rickettsia felis is an obligate intracellular bacterium capable of infecting ticks, fleas, lice, and other arthropods. This bacterium is classified as a member of the Transitional Group (TRG) Rickettsia. It is known the evidence of $R$. felis mutualistic and obligatory relationship with some eukaryote organisms. However, there aren't scientific accounts of $R$. felis and moths of the order Lepidoptera association. The current work reports the first identification of the bacteria $R$. felis in Phereoeca sp. For that, a polymerase chain reaction (PCR) assay using $g / t A$, ompA, and ompB genes was used. The nucleotide sequences showed $100 \%$ of identity with other Rickettsia felis sequences. The genus-level identification of the moth larvae was performed by morphological taxonomic keys and PCR analysis of the cytochrome oxidase I (COI) gene. The nucleotide sequenced showed $94.94 \%$ similarity with the species Phereoeca praecox. However, with the low number of sequences deposited in the databases, the species was classified as Phereoeca sp. The results suggest that $R$. felis may develop in an organism without blood-feeding behavior (Lepidoptera), as it has been demonstrated for booklice (Psocoptera). Further investigation is necessary in order to confirm pathogenic or mutualistic association with moths.
\end{abstract}

Keywords: Rickettsia felis, Phereoeca sp., taxonomic keys, polymerase chain reaction.

\section{Resumo}

Rickettsia felis é uma bactéria intracelular obrigatória capaz de infectar carrapatos, pulgas, piolhos e outros artrópodes. Essa bactéria é classificada como um membro do Grupo de Transição (TRG). Há evidência de que $R$. felis está relacionada a alguns organismos eucariotos em um relacionamento mutualístico e obrigatório. No entanto, nenhum relato científico mostra alguma relação entre $R$. felis e traças da ordem Lepidoptera. O presente trabalho relata a primeira identificação da bactéria $R$. felis em Phereoeca sp. Para isso, empregou-se um ensaio de reação em cadeia da polimerase (PCR) utilizando-se os genes $g / t A$, ompA e ompB. As sequências nucleotídicas mostraram 100\% de identidade com outras sequências de Rickettsia felis. Utilizando-se chaves taxonômicas morfológicas e análise por PCR do gene da citocromo oxidase I (COI) foi feita a identificação em nível de espécie da forma jovem das traças. O nucleotídeo sequenciado mostrou $94,94 \%$ de similaridade com a espécie Phereoeca praecox. Entretanto, com o baixo número de sequências depositadas nos bancos de dados, a espécie foi classificada como Phereoeca sp. Os resultados sugerem que $R$. felis pode se desenvolver em um organismo sem alimentação de sangue (Lepidoptera), assim como tem sido demonstrado para a espécie Liposcelis bostrychophila (Psocoptera). Mais investigações são necessárias para confirmar uma possível associação patogênica ou mutualística com traças.

Palavras-chave: Rickettsia felis, Phereoeca sp., chaves taxonômicas, reação em cadeia da polimerase. 


\section{Introduction}

Rickettsia felis (Azad et al., 1992) is an obligate intracellular bacterium capable of infecting ticks, fleas, lice, and other arthropods. This bacterium is an emerging pathogen with worldwide occurrence, classified as a Transitional Group (TRG) Rickettsia (Gillespie et al., 2007, 2018; Shpynov et al., 2018), although this classification is not completely accepted (Merhej \& Raoult, 2011).

R. felis is known as the causative agent of flea-borne spotted fever (Bouyer et al., 2001), which bacterial life cycle includes transovarial transmission, through fleas of the species Ctenocephalides felis (Labruna, 2009; Parola et al., 2009), infecting vertebrates hosts, mainly cats and dogs, showing cases of acute febrile illnesses for humans (Richards et al., 2010). In Africa, some studies have associated $R$. felis with patients that presented fever of unknown origin, being the infection diagnosed by PCR amplification of target genes for R. felis (Blanton \& Walker, 2017; Parola, 2011). However, there is an intense debate about its pathogenicity for humans (Labruna \& Walker, 2014).

Currently, there is evidence that some non-hematophagous organisms have associations with $R$. felis, for example, the booklouse Liposcelis bostrychophila (Insecta: Psocoptera), whose relationship with the bacterium is mutualistic and obligatory (Behar et al., 2010; Thepparit et al., 2011; Yusuf \& Turner, 2004). Genetic diversity was found between three different strains of $R$. felis isolates: $R$. felis str. LSU-Lb, present within L. bostrychophila colony (Thepparit et al., 2011); R. felis str. LSU, in C. felis colony (Pornwiroon et al., 2006); and R. felis str. URRWXCal2, also isolated from C. felis (Ogata et al., 2005). Based on data obtained from Gillespie et al. (2014), the strains associated with fleas ( $C$. felis) have a genetically highly divergent evolutionary history, despite sharing a familiar ancestral relative with the strain associated with booklouse (L. bostrychophila). Moreover, the transmission (vertical or horizontal) of rickettsial species has an important role whether the bacteria will be involved in a mutualistic or parasitic interaction. Another feature found in the study is that all three $R$. felis genomes have the pRF plasmid, however, the strain associated with booklouse exhibit an additional unique plasmid, pLbaR (association between L. bostrychophila and Rickettsia bacteria), not found in other Rickettsiales genomes. These analyses suggested that potential host specialization resulted from a genetic divergence, including evidence of host-specific strain variation (Gillespie et al., 2014; Brown \& Macaluso, 2016). However, no scientific accounts reported a relationship between $R$. felis and moths of the order Lepidoptera.

The moths belong to the order Lepidoptera, Tineidae family, household casebearer moths, feed on wool, cotton, silk, and other fabrics. The young form of the moths are larvae with a case built by themselves that serves for the pupal cocoon. The larvae can feed on remains animals in humid and dark places.

The current work reports, by molecular approach, the presence of the bacteria R. felis in Phereoeca sp. (Gozmany \& Vari, 1973) with the genus-level identification of the larvae, suggesting that the bacteria may be found in a nonblood-feeding organism.

\section{Materials and Methods}

\section{Sample collection}

A total of 50 household casebearer moths were collected in the larval stage in the city Ponte Nova/Minas Gerais, Brazil (20.4155 S 42.9026 W), in a residential environment. They were washed with water, maintained in $70 \%$ ethanol, and frozen at $-20^{\circ} \mathrm{C}$ until molecular biology analysis.

\section{DNA extraction, quantification, and quality}

Household casebearer moths were removed from $70 \%$ ethanol and separated into ten $1.5 \mathrm{~mL}$ tubes, each containing five individuals in the larval stage. For extraction of DNA, the phenol-chloroform method (Billings et al., 1998) was used, modified as described. First, moths were washed with hypochlorite solution (1\%) mixed by vortexing, discarding the hypochlorite after this step. Posteriorly, they were washed with $70 \%$ ethanol, mixed by vortexing, and discarded the solution. The samples were washed three times with ultrapure water, mixing and discarding the water after each wash. A $200 \mu \mathrm{L}$ lysis buffer ( $\mathrm{NaCl} 0.1 \mathrm{M}$; TRIS-HCl 0.21M pH 8; EDTA 0.05M and SDS 0.5\%) were added and the samples was triturated with a microtube plastic pestle. The mixture was placed in a water bath for $30 \mathrm{~min}$ at $37^{\circ} \mathrm{C}$. After this step, $20 \mu \mathrm{L}$ of proteinase $\mathrm{K}(20 \mathrm{mg} / \mathrm{mL})$ was added, incubating the mixture overnight at $55^{\circ} \mathrm{C}$. After incubation, $200 \mu \mathrm{L}$ phenol was added and the tubes mixed by inversion for 5 min before centrifugation at $14,000 \times$ for $2 \mathrm{~min}$. The supernatant was transferred to a new tube and $100 \mu \mathrm{L}$ phenol and $100 \mu \mathrm{L}$ chloroform/ 
isoamyl alcohol (4:1) were added to each tube, mixed by inversion and centrifuging at 14,000xg for 2 min, transferring the supernatant to a new tube. This step was repeated eight times to ensure maximum deproteinization due to the cocoon and other impurities. After deproteinization, $200 \mu \mathrm{L}$ chloroform/isoamyl alcohol was added, and the sample was centrifuged at 14,000xg for 2 min transferring the supernatant to a new tube. The DNA was precipitated with half of the volume of sodium acetate $7,5 \mathrm{M}$ and two volumes of $100 \%$ ethanol, incubating overnight at $-20^{\circ} \mathrm{C}$. After this step, the samples were centrifuged at $14,000 \times$ for $10 \mathrm{~min}$. The supernatant was discarded, and the pellet was washed with $400 \mu \mathrm{L} 70 \%$ ethanol by inversion before centrifugation at 14,000xg for $10 \mathrm{~min}$. The ethanol was discarded and evaporated, while the remaining pellet was resuspended in $50 \mu \mathrm{L}$ ultrapure water.

The quality of DNA extraction was verified in $1 \%$ agarose gel using $5 \mu \mathrm{L}$ DNA of each sample extracted. The results were visualized under UV light (L·PIX photodocumentary system - Loccus Biotechnology, Brazil). The quantification was performed using a NanoDrop spectrophotometer (Thermo Scientific) at 230, 260, and $280 \mathrm{~nm}$, and the ratio results A260/230, A260/280, and concentration were annotated. The samples were maintained frozen at $-20^{\circ} \mathrm{C}$ to preserve the biological material for the next analysis.

\section{Genus Rickettsia detection by PCR and sequencing}

For genus Rickettsia screening in household casebearer moths, PCRs were performed with the extracted DNA samples. For the traditional PCR analysis, the target citrate sintase $(g / t A)$ gene was chosen using the primers CS78 (5' - GCAAGTATCGGTGAGGATGTAAT - 3') (forward) and CS-323 (5' - GCTTCCTTAAAATTCAATAAATCAGGAT - 3') (reverse) that amplify a 401 bp fragment for the all species of the genus Rickettsia (Labruna et al., 2004). In addition, for each sample was done a set of PCR using the primers 120-M59 (5' - CCGCAGGGTTGGTAACTGC - 3') (forward) and 120-807 (5' - CCTTTTAGATTACCGCCTAA - 3') (reverse) targeting fragments of the genes ompB that amplify a 862 bp fragment (Roux \& Raoult, 2000); the primers Rr190.70p (5' - ATGGCGAATATTTCTCCAAAA - 3') (forward) and Rr190.602n (5' - AGTGCAGCATTCGCTCCCCCT - 3') (reverse) targeting fragments of the genes ompA that amplify a 532 bp fragment (Regnery et al., 1991).

The PCR was performed in a $25 \mu \mathrm{L}$ reaction mixture containing $12.6 \mu \mathrm{L}$ ultra-pure water, $2.5 \mu \mathrm{l} \mathrm{Taq} \mathrm{10x} \mathrm{buffer,}$ $2.5 \mu \mathrm{l}$ of $2 \mathrm{mM}$ dNTP, $1.5 \mu \mathrm{l}$ of $1.25 \mathrm{mM} \mathrm{MgCl}_{2}, 1.5 \mu \mathrm{l}$ of each primer $(10 \mu \mathrm{M}), 0.4 \mu \mathrm{L}$ DNA polymerase and $2.5 \mu \mathrm{L}$ of the DNA sample. For positive control, a sample with $R$. rickettsii and for the negative control was used ultra-pure water.

The amplification was performed in a DNA thermocycler (Biosystems - Biocycler MJ25+, Brazil) under conditions described in Table 1.

PCR products were analyzed on $1.0 \%$ agarose gels stained with ethidium bromide $(0.5 \mu \mathrm{g} / \mathrm{L})$, using five $\mu \mathrm{L}$ of each product and the molecular weight of $100 \mathrm{bp}$. Positive samples were purified and concentrated using the Purelink ${ }^{\mathrm{TM}}$ PCR purification kit (Invitrogen Corp., USA), according to the manufacturer's recommendations. Sequencing was performed in Macrogen Inc. (South Korea) according to the recommended protocol. The sequences generated were viewed and analyzed with the software Chromas Lite v2.01 (Huang \& Madan, 1999). After removal of lowquality sequences, consensus sequences were obtained using the CAP3 sequence assembly program using the files analyzed from software Chromas Lite v2.01. The new sequence was deposited in the GenBank database and compared with others using the Basic Local Alignment Search Tool (BLAST).

Table 1. Amplification program to the PCR.

\begin{tabular}{|c|c|c|c|c|c|c|}
\hline Gene & \multicolumn{2}{|c|}{ gltA } & \multicolumn{2}{|c|}{ ompA } & \multicolumn{2}{|c|}{ ompB } \\
\hline Denaturation & $5^{\prime}$ & $95^{\circ} \mathrm{C}$ & $5^{\prime}$ & $95^{\circ} \mathrm{C}$ & $3^{\prime}$ & $95^{\circ} \mathrm{C}$ \\
\hline Cycles & \multicolumn{2}{|c|}{40} & \multicolumn{2}{|c|}{35} & \multicolumn{2}{|c|}{40} \\
\hline Melting & $30 "$ & $95^{\circ} \mathrm{C}$ & $20^{\prime \prime}$ & $95^{\circ} \mathrm{C}$ & $30 "$ & $95^{\circ} \mathrm{C}$ \\
\hline Annealing & $30 "$ & $48^{\circ} \mathrm{C}$ & $30 "$ & $72^{\circ} \mathrm{C}$ & $30^{\prime \prime}$ & $50^{\circ} \mathrm{C}$ \\
\hline Extension & $30 "$ & $72^{\circ} \mathrm{C}$ & $2 \min$ & $72^{\circ} \mathrm{C}$ & $1^{\prime} 30^{\prime \prime}$ & $72^{\circ} \mathrm{C}$ \\
\hline Final extension & $7^{\prime}$ & $72^{\circ} \mathrm{C}$ & $7^{\prime}$ & $72^{\circ} \mathrm{C}$ & $7^{\prime}$ & $72^{\circ} \mathrm{C}$ \\
\hline Expected Fragment & \multicolumn{2}{|c|}{401 bp } & \multicolumn{2}{|c|}{$532 \mathrm{bp}$} & \multicolumn{2}{|c|}{862 bp } \\
\hline Reference & \multicolumn{2}{|c|}{ Labruna et al. (2004) } & \multicolumn{2}{|c|}{ Regnery et al. (1991) } & \multicolumn{2}{|c|}{ Roux \& Raoult (2000) } \\
\hline
\end{tabular}




\section{Phylogenetic analysis}

Multiple sequence alignment was performed using MEGA version 7 (Kumar et al., 2016), which sequence obtained was analyzed by Clustal W (gap opening $=15$, extension $=6.66$, delay divergent $=30 \%$, transition weight $=0.5$ and DNA weight matrix = IUB) with other sequences of Rickettsia species deposited in the NCBI. After alignment, trees were constructed using two algorithms: Maximum Likelihood (phylogeny reconstruction statistical method) and Neighbor-Joining (distance method) (Saitou \& Nei, 1987). Maximum Likelihood method was based on the following parameters: Tamura-Nei substitution model (Tamura \& Nei, 1993); substitutions type = nucleotide; rates among sites = uniform rates; gaps/missing data treatment = complete deletion; ML heuristic method = Nearest-NeighborInterchange (NNI); initial tree for $\mathrm{ML}$ = initial tree automatically (Default $-\mathrm{NJ} / \mathrm{BioNJ}$ ); and branch swap filter = none. The Neighbor-Joining tree was constructed using the following parameters: Maximum Composite Likelihood method (Tamura \& Nei, 1993); substitutions to include = d: Transitions + Transversions; rates among sites = uniform rates; pattern among lineages = same (homogeneous); and gaps/missing data treatment = complete deletion. In both phylogeny test, the bootstrap method was used with 1,000 replicates.

\section{Morphological identification of moths by using published taxonomic keys}

Partial identification and classification were made by running the taxonomic keys (Hinton, 1956; Carter, 1984; Gilligan \& Passoa, 2014).

\section{Moths' PCR identification and sequencing}

PCR was done with the DNA samples extracted from moths. For the traditional PCR analysis, the target cytochrome oxidase I (COI) gene was chosen using the primer pair LCO1490 (5' - GGTCAACAAATCATAAAGATATTGG - 3') and HCO2198 (5' - TAAACTTCAGGGTGACCAAAAAATCA - 3') that amplify a 658 bp fragment (Folmer et al., 1994).

PCR was performed in a $25 \mu \mathrm{L}$ reaction mixture containing $12.6 \mu \mathrm{L}$ ultra-pure water, $2.5 \mu \mathrm{l} \mathrm{Taq} \mathrm{10x} \mathrm{buffer,} 2.5 \mu \mathrm{l}$ of $2 \mathrm{mM}$ dNTP, $1.5 \mu \mathrm{l}$ of $1.25 \mathrm{mM} \mathrm{MgCl}{ }_{2}, 1.5 \mu \mathrm{l}$ of each primer $(10 \mu \mathrm{M}), 0.4 \mu \mathrm{L}$ DNA polymerase, and $2.5 \mu \mathrm{L}$ of the DNA sample. For negative control, ultra-pure water was used.

Amplification was performed in a DNA thermocycler (Biosystems - Biocycler MJ25+) following an initial cycle of $1^{\prime}$ at $94^{\circ} \mathrm{C}$; five cycles on $1^{\prime}$ at $94^{\circ} \mathrm{C}, 1.5^{\prime}$ at $45^{\circ} \mathrm{C}$ and $1.5^{\prime}$ at $72^{\circ} \mathrm{C} ; 35$ cycles of $1^{\prime}$ at $94^{\circ} \mathrm{C}, 1.5^{\prime}$ at $50^{\circ} \mathrm{C}$ and $1^{\prime}$ at $72^{\circ} \mathrm{C}$; finishing with a final cycle of $5^{\prime}$ at $72^{\circ} \mathrm{C}$ (Hebert et al., 2003).

The PCR products were analyzed on $1.0 \%$ agarose gels stained with ethidium bromide $(0,5 \mu \mathrm{g} / \mathrm{L})$, using five $\mu \mathrm{L}$ of each product and the molecular weight of $100 \mathrm{bp}$. Positive samples were purified and concentrated using the Purelink ${ }^{\mathrm{TM}}$ PCR purification kit (Invitrogen Corp., USA), according to the manufacturer's recommendations. Sequencing was performed by Myleus Biotechnology (Brazil) according to the recommended protocol. The sequences generated were viewed and analyzed with the software Chromas Lite 2.01 (Huang \& Madan, 1999). After removal of low-quality sequences, consensus sequences were obtained using the CAP3 sequence assembly program using the files analyzed from software Chromas Lite v2.01. The new sequence was deposited in the GenBank database and compared with others using the Basic Local Alignment Search Tool (BLAST).

\section{Phylogenetic analysis of household casebearer moths}

Multiple sequence alignment was performed using MEGA version 7 (Kumar et al., 2016), which sequence obtained was analyzed by Clustal W (gap opening $=15$, extension $=6.66$, delay divergent $=30 \%$, transition weight $=0.5$ and DNA weight matrix = IUB) with other sequences of Phereoeca species deposited in the NCBI. After alignment, trees were constructed using two algorithms: Maximum Likelihood (phylogeny reconstruction statistical method) and Neighbor-Joining (distance method) (Saitou \& Nei, 1987). Maximum Likelihood method was based on the following parameters: Tamura-Nei substitution model (Tamura \& Nei, 1993); substitutions type = nucleotide; rates among sites = uniform rates; gaps/missing data treatment = complete deletion; ML heuristic method = Nearest-NeighborInterchange (NNI); initial tree for $\mathrm{ML}$ = initial tree automatically (Default $-\mathrm{NJ} / \mathrm{BioNJ}$ ); and branch swap filter = none. The Neighbor-Joining tree was constructed using the following parameters: Maximum Composite Likelihood method (Tamura \& Nei, 1993); substitutions to include = d: Transitions + Transversions; rates among sites = uniform rates; pattern among lineages = same (homogeneous); and gaps/missing data treatment = complete deletion. In both phylogeny test, the bootstrap method was used with 1,000 replicates. 


\section{Results}

A total of five pools of ten household casebearer mouths $(n=50)$ were analyzed. One pool sample showed PCR product of the expected size for g/tA using the primers CS-78 and CS-323, indicating the genus Rickettsia. For the primers 120-M59, 120-807, Rr190.70p, and Rr190.602n, no PCR products were obtained. Nucleotide sequence was analyzed by BLAST, showing $100 \%$ of identity with other Rickettsia felis sequences (MG952933.1; KY172878.1; KY172869.1, KY172875.1). This sequence was deposited in the GenBank with accession number KF015600.1, named Rickettsia felis isolate UFV1 citrate synthase ( $g / t A)$ gene, partial CDS.

A phylogenetic tree was constructed based on other species as $R$. akari, R. amblyommii (new classification is $R$. amblyommatis), $R$. rickettsii, $R$. typhi and $R$. prowazekii. The obtained sequence was grouped within other sequences of R. felis obtained from NCBI, which showed $99 \%$ bootstrap support into the same clade to the Maximum Likelihood tree (Figure 1A) and $87 \%$ bootstrap support in the same clade to the Neighbor-Joining tree (Figure 1B).

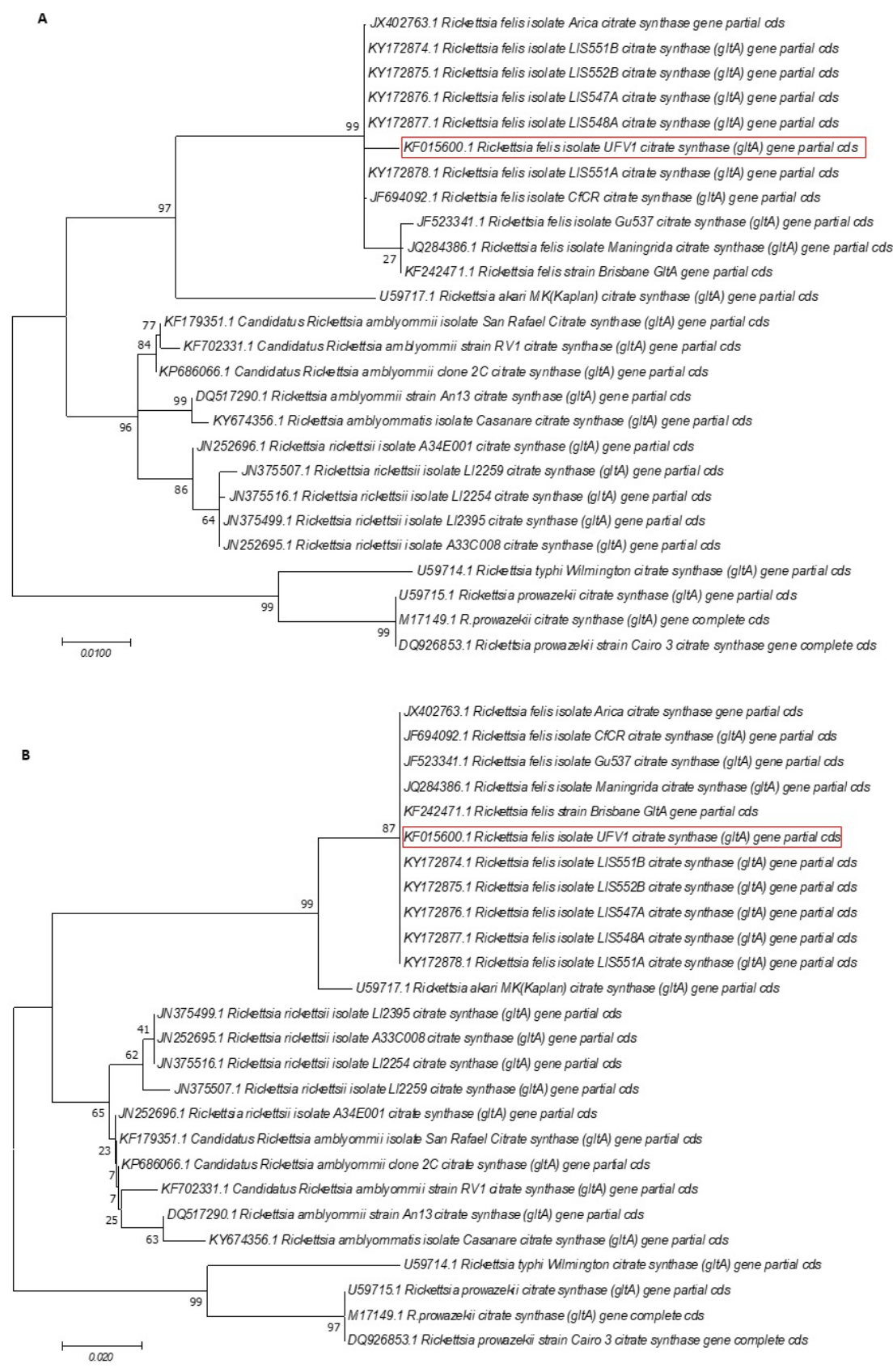

Figure 1. Phylogeny tree of $R$. felis found in household casebearer moths. Twenty-five sequences of different genus Rickettsia bacteria were used to compare the relation between our sequence and other deposited in GenBank. The names of Rickettsia species sequences are described in each strain with the bootstrap number. (A) Maximum Likelihood and (B) Neighbor-Joining. 
The morphological identification of moths through taxonomic keys showed that the moths of the order Lepidoptera are inserted into the Tineidae family (Carter, 1984; Gilligan \& Passoa, 2014). The larvae phase has a case made of silk, loose or fixed, open at both ends, dragging them as they move. The household casebearer moths without secondary bristles and dotted bristle warts; showing three thoracic segments and ten abdominal segments (Figure 2A-1), without abdominal glands; prothorax with prespiracular spire $(L)$ separate from ribcage or undeveloped (Figure 2B-1); with three pairs of short abdominal prolegs (extra legs) with hooks arranged in a circle or penelipse and legs in the thoracic region (Figure 2A-2); a prothorax with prespiracular bristle (L) about twice as far from spiracles (Figure 2B-1, 2); and head with none, six or two stemmata on each side (simple or ocelli eyes) (Figure 2A-4).

Phereoeca genus presents a flat and fusiform case that opens at both ends. It consists of silk, sand, insect droppings, and arthropod remnants added to the outside of the structure (Hinton, 1956). The larval presents darkcolored head, prothorax, mesothorax, and metathorax; with white-colored abdominal segments and proleg in the tenth segment is attached inside the case to facilitate the locomotion and weak body bristles.

The molecular identification of moths showed PCR product of the expected size for primers LCO1490 and HCO2198, targeting cytochrome oxidase I (COI) gene (Folmer et al., 1994). This sample was sequenced and obtained by the nucleotide sequence analyzed by BLAST, showing $94.94 \%$ of similarity with Phereoeca praecox (KY575118.1). Due to the low number of sequences deposited in the databases, the species was classified and deposited in the GenBank with the accession number MH540351.1, named Phereoeca sp. isolate the UFV1 cytochrome c oxidase subunit I gene, partial CDs; mitochondrial.

The phylogenetic tree was based on other Phereoeca praecox and Phereoeca uterella. The sequence was grouped within other sequences of Phereoeca praecox obtained from NCBI, showing $99 \%$ bootstrap support into the same clade to the Maximum Likelihood tree and Neighbor-Joining tree (Figure 3).

A 3

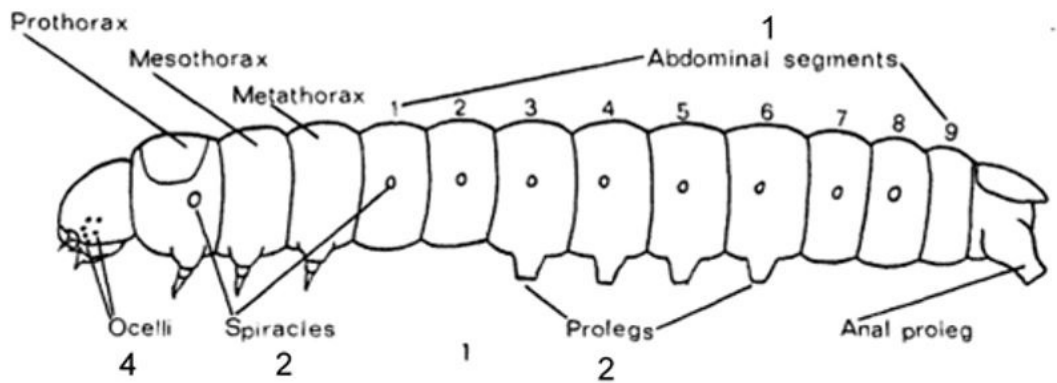

B

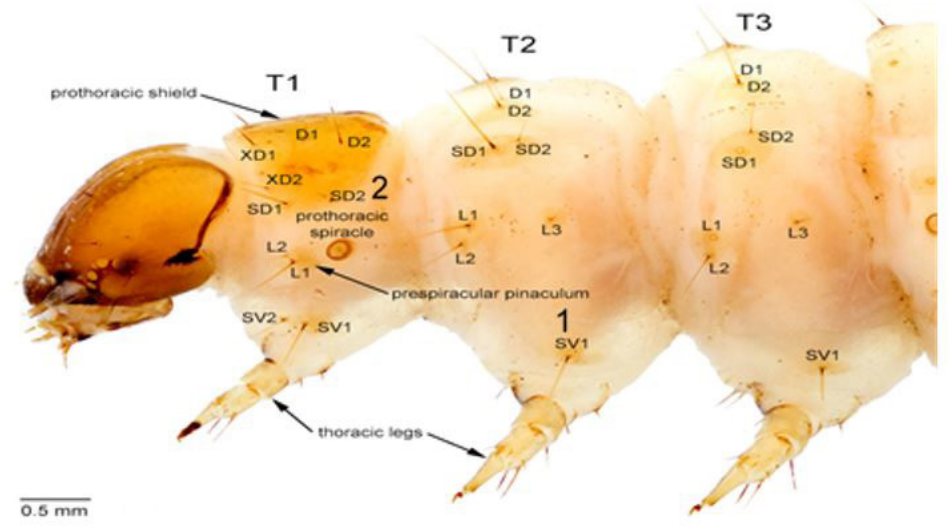

Figure 2. Morphological identification of larval stage. (A) schematic drawing of the larvae structures of the Tineidae family with thoracic and abdominal segments (1), abdominal and thoracic legs (2), prothorax (3) and the head with ocelli eyes (4) (Carter, 1984); (B) the prespiracular pinaculum (1) and the prothoracic spiracle (2) (Gilligan \& Passoa, 2014). 


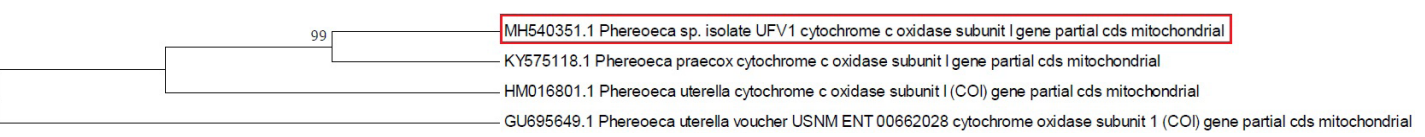

Figure 3. Comparison between Phereoeca sp. identified and the other sequences present in GenBank. Bootstrap support is $99 \%$ into the clade to the Maximum Likelihood tree and Neighbor-Joining tree.

\section{Discussion}

The present study reports by the first time the $R$. felis in the household casebearer moths. Interestingly, the species identified, Phereoeca sp., does not have a hematophagous behavior. This suggests that during the larval stage, the household casebearer moths may feed on animal remains or infected fleas' feces. Such a feature may have approximated the moths of remains that were contaminated with the bacteria, whose recent studies have related $R$. felis to several hosts that do not feed on blood (Behar et al., 2010; Thepparit et al., 2011; Legendre \& Macaluso, 2017).

Moths of the Lepidoptera order (Linnaeus, 1735) were found in a home environment with dogs and other hosts of the flea Ctenocephalides canis, one of the main vectors of $R$. felis. The propagation of this bacteria occurs by transovarial transmission through fleas (Parola et al., 2009) which predominantly parasite cats and dogs, being widespread to vertebrate hosts through blood-feeding or fleas' feces (Azad et al., 1997). However, there is a need of laboratory experiments ensuring a controlled environment of infection with $R$. felis to elucidate two attractive hypotheses: 1) if the presence of the bacterium in moths is maintained naturally, indicating a possible mutualistic interaction, or; 2) only presents an accidental infection with moths feeding on dead fleas or feces infected. Although $R$. felis strain LSU-Lb has mutualist and obligatory relationship with L. bostrychophila, its potential transmission to vertebrates needs to be evaluated (Gillespie et al., 2014).

Molecular identification of $R$. felis after sequencing showed high similarity with other sequences in the GenBank grouped in the same clade, showing $99 \%$ bootstrap to the Maximum Likelihood tree and $87 \%$ bootstrap support in the same clade to the Neighbor-Joining tree. The morphological identification of the moth using keys was not enough for species-level identification. The family Tineidae and the Phereoeca genus were identified using taxonomic keys (Carter, 1984; Gilligan \& Passoa, 2014) and the literature (Hinton, 1956). PCR was used to improve the identification, whose species found after sequencing had $94 \%$ of identity with $P$. praecox. However, with the low number of sequences deposited in the databases, the species was classified as Phereoeca sp. The molecular identification of Phereoeca sp. after sequencing showed high similarity with other sequences in the GenBank grouped in the same clade, showing 99\% bootstrap to the Maximum Likelihood tree and the Neighbor-Joining tree.

\section{Conclusion}

The current work showed, in first hand, moths containing $R$. felis, an unusual invertebrate host. Due to the lack of reports of this interaction, it is necessary to study the mechanism that spreads this bacterium to a non-hematophagous host, to clarify if the contact is accidental or; $R$. felis is a mutualistic bacterium in moths or; $R$. felis is potential pathogenic to vertebrates, sharing the same habitat with moths like demonstrated herein.

\section{Acknowledgements}

This work was supported by Fundação de Amparo à Pesquisa do Estado de Minas Gerais (FAPEMIG), Conselho Nacional de Desenvolvimento Científico e Tecnológico (CNPq) and Coordenação de Aperfeiçoamento de Pessoal de Nível Superior (CAPES). C.M. is Productive Research grant recipient from Brazilian National Council for Scientific and Technological Development (CNPq).

\section{References}

Azad AF, Radulovic S, Higgins JA, Noden BH, Troyer JM. Flea-borne rickettsioses: ecologic considerations. Emerg Infect Dis 1997; 3(3): 319-327. http://dx.doi.org/10.3201/eid0303.970308. PMid:9284376.

Azad AF, Sacci JB Jr, Nelson WM, Dasch GA, Schmidtmann ET, Carl M. Genetic characterization and transovarial transmission of a typhus-like Rickettsia found in cat fleas. Proc Natl Acad Sci USA 1992; 89(1): 43-46. http://dx.doi.org/10.1073/pnas.89.1.43. PMid:1729713. 
Behar A, McCormick LJ, Perlman SJ. Rickettsia felis infection in a common household insect pest, Liposcelis bostrychophila (Psocoptera: liposcelidae). App/ Environ Microbio/ 2010; 76(7): 2280-2285. http://dx.doi.org/10.1128/AEM.00026-10. PMid:20139311.

Billings AN, Yu XJ, Teel PD, Walker DH. Detection of a spotted fever group Rickettsia in Amblyomma cajennense (Acari: Ixodidae) in South Texas. J Med Entomol 1998; 35(4): 474-478. http://dx.doi.org/10.1093/jmedent/35.4.474. PMid:9701930.

Blanton LS, Walker DH. Flea-borne rickettsioses and rickettsiae. Am J Trop Med Hyg 2017; 96(1): 53-56. http://dx.doi.org/10.4269/ ajtmh.16-0537. PMid:27799640.

Bouyer DH, Stenos J, Crocquet-Valdes P, Moron CG, Popov VL, Zavala-Velazquez JE, et al. Rickettsia felis: molecular characterization of a new member of the spotted fever group. Int J Syst Evol Microbio/ 2001; 51(Pt 2 ): 339-347. http://dx.doi.org/10.1099/0020771351-2-339. PMid:11321078.

Brown LD, Macaluso KR. Rickettsia felis, an Emerging Flea-Borne Rickettsiosis. Curr Trop Med Rep 2016; 3(2): 27-39. http://dx.doi. org/10.1007/s40475-016-0070-6. PMid:27340613.

Carter DJ. Pest Lepidoptera of Europe: with special reference to the British Isles. Dordrecht: Springer London; 1984.

Folmer O, Black M, Hoeh W, Lutz R, Vrijenhoek R. DNA primers for amplification of mitochondrial cytochrome c oxidase subunit I from diverse metazoan invertebrates. Mol Mar Biol Biotechnol 1994; 3(5): 294-299. PMid:7881515.

Gillespie J, Beier MS, Rahman MS, Ammerman NC, Shallom JM, Purkayastha A, et al. Plasmids and rickettsial evolution: insight from Rickettsia felis. PLoS One 2007; 2(3): e266. http://dx.doi.org/10.1371/journal.pone.0000266. PMid:17342200.

Gillespie JJ, Driscoll TP, Verhoeve VI, Utsuki T, Husseneder C, Chouljenko VN, et al. Genomic diversification in strains of Rickettsia felis Isolated from different arthropods. Genome Biol Evo/ 2014; 7(1): 35-56. http://dx.doi.org/10.1093/gbe/evu262. PMid:25477419.

Gillespie JJ, Williams K, Shukla M, Snyder EE, Nordberg EK, Ceraul SM, et al. Rickettsia phylogenomics: unwinding the intricacies of obligate intracellular life. PLoS One 2018; 3(4): e2018. http://dx.doi.org/10.1371/journal.pone.0002018. PMid:19194535.

Gilligan TM, Passoa SC. LepIntercept, an identification resource for intercepted Lepidoptera larvae [online]. Fort Collins, CO: USDA/APHIS/PPQ/S\&T; 2014. Identification Technology Program (ITP). Available from: http://idtools.org/id/leps/lepintercept/ information.html

Gozmany L, Vari L. The Tineidae of Ethiopian Region. Pretoria: Transvaal Museum; 1973.

Hebert PD, Cywinska A, Ball SL, deWaard JR. Biological identifications through DNA barcodes. Proc Bio/ Sci 2003; 270(1512): 313321. http://dx.doi.org/10.1098/rspb.2002.2218. PMid:12614582.

Hinton HE. The larvae of the species of Tineidae of economic importance. Bull Entomol Res 1956; 47(2): 251-346. http://dx.doi. org/10.1017/S0007485300046708.

Huang X, Madan A. CAP3: a DNA sequence assembly program. Genome Res 1999; 9(9): 868-877. http://dx.doi.org/10.1101/ gr.9.9.868. PMid:10508846.

Kumar S, Stecher G, Tamura K. MEGA7: Molecular Evolutionary Genetics Analysis version 7.0 for bigger datasets. Mol Biol Evol 2016; 33(7): 1870-1874. http://dx.doi.org/10.1093/molbev/msw054. PMid:27004904.

Labruna MB, Walker DH. Rickettsia felis and Changing Paradigms about Pathogenic Rickettsiae. Emerg Infect Dis 2014; 20(10): 1768-1769. http://dx.doi.org/10.3201/eid2010.131797. PMid:25271441.

Labruna MB, Whitworth T, Horta MC, Bouyer DH, Mcbride JW, Pinter A, et al. Rickettsia species infecting Amblyomma cooperi ticks from an area in State of São Paulo, Brazil, where Brazilian spotted fever is endemic. J Clin Microbiol 2004; 42(1): 90-98. http:// dx.doi.org/10.1128/JCM.42.1.90-98.2004. PMid:14715737.

Labruna MB. Ecology of Rickettsia in South America. Ann N Y Acad Sci 2009; 1166(1): 156-166. http://dx.doi.org/10.1111/j.17496632.2009.04516.x. PMid:19538276.

Legendre KP, Macaluso KR. Rickettsia felis: a review of transmission mechanisms of an emerging pathogen. Trop Med Infect Dis 2017; 2(4): 64. http://dx.doi.org/10.3390/tropicalmed2040064. PMid:30270921.

Merhej V, Raoult D. Rickettsial evolution in the light of comparative genomics. Biol Rev Camb Philos Soc 2011; 86(2): $379-405$. http://dx.doi.org/10.1111/j.1469-185X.2010.00151.x. PMid:20716256.

Ogata H, Robert C, Audic S, Robineau S, Blanc G, Fournier PE, et al. Rickettsia felis, from culture to genome sequencing. Ann $N$ Y Acad Sci 2005; 1063(1): 26-34. http://dx.doi.org/10.1196/annals.1355.004. PMid:16481487.

Parola P, Labruna MB, Raoult D. Tick-Borne Rickettsioses in America: unanswered questions and emerging disease. Curr Infect Dis Rep 2009; 11(1): 40-50. http://dx.doi.org/10.1007/s11908-009-0007-5. PMid:19094824.

Parola P. Rickettsia felis: from a rare disease in the USA to a common cause of fever in sub-Saharan Africa. Clin Microbiol Infect 2011; 17(7): 996-1000. http://dx.doi.org/10.1111/j.1469-0691.2011.03516.x. PMid:21722253. 
Pornwiroon W, Pourciau SS, Foil LD, Macaluso KR. Rickettsia felis from cat fleas: isolation and culture in a tick-derived cell line. Appl Environ Microbiol 2006; 72(8): 5589-5595. http://dx.doi.org/10.1128/AEM.00532-06. PMid:16885313.

Regnery RL, Spruill CL, Plikaytis BD. Genotypic identification of rickettsiae and estimation of intraspecies sequence divergence for portions of two rickettsial genes. J Bacteriol 1991; 173(5): 1576-1589. http://dx.doi.org/10.1128/JB.173.5.1576-1589.1991. PMid:1671856.

Richards AL, Jiang J, Omulo S, Dare R, Abdirahman K, Ali A, et al. Human Infection with Rickettsia felis, Kenya. Emerg Infect Dis 2010; 16(7): 1081-1086. http://dx.doi.org/10.3201/eid1607.091885. PMid:20587178.

Roux V, Raoult D. Phylogenetic analysis of members of the genus Rickettsia using the gene encoding the outer-membrane protein rOmpB (ompB). Int J Syst Evol Microbio/ 2000; 50(Pt 4 ): 1449-1455. http://dx.doi.org/10.1099/00207713-50-4-1449. PMid:10939649.

Saitou N, Nei M. The neighbor-joining method: a new method for reconstructing phylogenetic trees. Mol Biol Evol 1987; 4(4): 406-425. http://dx.doi.org/10.1093/oxfordjournals.molbev.a040454. PMid:3447015.

Shpynov SN, Fournier PE, Pozdnichenko NN, Gumenuk AS, Skiba AA. New approaches in the systematics of rickettsiae. New Microbes New Infect 2018; 23: 93-102. http://dx.doi.org/10.1016/j.nmni.2018.02.012. PMid:29692912.

Tamura K, Nei M. Estimation of the number of nucleotide substitutions in the control region of mitochondrial DNA in humans and chimpanzees. Mol Biol Evol 1993; 10(3): 512-526. http://dx.doi.org/10.1093/oxfordjournals.molbev.a040023. PMid:8336541.

Thepparit C, Sunyakumthorn P, Guillotte ML, Popov VL, Foil LD, Macaluso KR. Isolation of a rickettsial pathogen from a nonhematophagous arthropod. PLoS One 2011; 6(1): e16396. http://dx.doi.org/10.1371/journal.pone.0016396. PMid:21283549.

Yusuf M, Turner B. Characterizations of Wolbachia-like bacteria isolated from the parthenogenetic stored-product pest psocid Liposcelis bostrychophila (Badonnel) (Psocoptera). J Stored Prod Res 2004; 40(2): 207-225. http://dx.doi.org/10.1016/S0022474X(02)00098-X. 